\title{
INTERACTIVE TEXTBOOK AND ITS DIDACTIC USE IN OBTAINING AND PROCESSING GEOGRAPHICAL INFORMATION
}

\author{
Martina ŠKODOV $\boldsymbol{A}^{*}$, Univerzita Mateja Bela v Banskej Bystrici, Slovenská \\ republika \\ Andrej MRAČNÍK, Univerzita Mateja Bela v Banskej Bystrici, Slovenská \\ republika
}

Received: 1. 6. 2020 / Accepted: 24. 11. 2020

Article type: Research study

DOI: $10.5507 /$ jtie. 2020.020

Abstract: The development and creation of interactive textbooks require special conditions and the fulfillment of specific requirements. The paper presents a teaching aid - an interactive textbook that has the potential to involve students in discovering and using online information about their region. Using its example, we identify the essential requirements for interactive textbooks and several aspects of their creation. In addition to the technical features of the textbook, a high standard of information processing is especially important in terms of content and learning needs. The results of our experience in developing and evaluating an interactive textbook can be useful for potential authors of other interactive textbooks.

Keywords: interactive textbook, school geography, educational technologies

\section{INTERAKTÍVNA UČEBNICA A JEJ DIDAKTICKÉ VYUŽITIE PRI ZÍSKAVANÍ A SPRACOVANÍ GEOGRAFICKÝCH INFORMÁCIÍ}

Abstrakt: Vývoj a tvorba interaktívnych učebnic vyžaduje osobitné podmienky a plnenie špecifických požiadaviek. Príspevok predstavuje učebnú pomôcku interaktívnu učebnicu, ktorá má potenciál zapojit žiakov do objavovania a využivania online informácií o ich regióne. Na jej príklade identifikujeme najdôležitejšie požiadavky na interaktívne učebnice a viaceré aspekty ich tvorby. Okrem technických vlastností učebnice je dôležitý najmä vysoký štandard spracovania informácií z hl'adiska obsahu i potrieb učenia sa. Výsledky našich skúseností pri vývoji a hodnoteni interaktívnej učebnice môžu byt' užitočné pre potenciálnych tvorcov d'alšich interaktivnych učebnic.

Kl'účové slová: interaktívna učebnica, školská geografia, edukačné technológie

*Autor pro korespondenci: martina.skodova@umb.sk 


\section{Introduction}

Nowadays, traditional methods and forms of education are increasingly complementing more modern teaching methods. Schools usually already have computer rooms, tablets and internet access in all classrooms. Information and communication technologies have become a standard part of students' personal lives. There is a precondition for greater use of various educational technologies in the subject of geography, which is extremely suitable for such an implementation. One of the goals of ŠVP geography innovations was to support the individual preferences of teachers in the introduction of progressive teaching methods with the support of digital technologies (Karolčík et al., 2016).

Consequently, geography teachers are required to orient themselves in several educational technologies (web applications, databases, mapping programs and graphs) and the possibilities of their didactic use in the context of specific topics and across several topics and subjects. However, research (e.g. Polly et al., 2010) shows that teachers still tend to see digital technologies only as a tool for mediating educational content and not as a means of applying effective teaching methods. For this reason, several projects are currently (and in the recent past) implemented in Slovakia, the common goal of the effort to innovate teaching methods using digital technologies in various phases of the teaching process (more Gregorová, 2018; Csachová, 2020). However, most of them have a broader focus and the outputs of several of them are not freely available for teachers. One of the complex solutions is an interactive textbook (hereinafter "i-textbook"), which in one place gathers current geographic information in various forms and several examples of learning activities in which students use the most appropriate of currently available web applications.

Using the interactive content of the textbook provides both the teacher and the students a much wider range of options in how to obtain and process information than in using printed textbooks and publications or searching for relevant information only using the Internet. In the process of creating and revising the didactic content of the textbook, the participation of teachers from practice is necessary. The aim of the paper is based on the experience from the creation and evaluation of a specific i-textbook to identify the most critical aspects of the implementation of $\mathrm{i}$-textbooks and to submit recommendations on how to create them.

\section{Digital education technologies and interactive textbooks}

Education in the 21st century is facing great changes and challenges that reflect the needs of today's society. These include the situation we face today (pandemic), where education is dominated by distance forms and e-learning is becoming an essential part of it. Due to the rapid development of information and 
communication technologies (Wellington, 2005), but also research in the field of cognitive psychology, increased emphasis is placed on the quality of digital educational technologies. The subject of research is both which technologies are suitable for use in education (Martin et al., 2011) but also the study of their benefits and limitations (Grant \& Mims, 2009; Mayer et al., 2001). The benefits include the development of critical, constructive and creative thinking of students, the ability to cooperate, use sources of information effectively, professional text, images, videos, interactive maps (reading comprehension, processing of textual information, orientation in the text structure, searching and sorting essential information, inference of knowledge, orientation on maps, etc.) (Mázorová, 2010). Research also points to improved learning outcomes (Donnell et al., 2014) and increased student motivation (Stelzer et al., 2009; Chen et al., 2010).

There are two perspectives on the definition of digital educational technologies. The first perspective, held by, e.g. Karolč́k et al. (2019), emphasizes the pedagogical nature of the product. Such a product should be directly designed and tested for educational purposes as a tool to achieve learning objectives. It should also respect the approved pedagogical documentation as well as generally accepted methodological procedures. However, these binding documents should not strictly delimit them.

On the contrary, the second view rejects any strict delimitation of the set of educational solutions. It is based on the fact that any technology or software becomes truly educational only at the moment of its application to the teaching process. For example Kormancová (2018) considers as educational technologies all products that are used to support teaching and learning. Due to the existence of the second opinion, it is necessary to distinguish between technologies created directly for education and technologies that were not directly created for educational purposes but are still implemented in education. In both cases, however, it is necessary to test the developed products in standard school conditions.

Several authors deal with the categorization of educational technologies (e.g. Grant \& Mims, 2009; Karolčík et al., 2015). Considering their categorization according to Karolčík et al. (2015), the i-textbook can be classified as an instructional program (software solutions that partially replace the teacher in the interpretation of the new curriculum, its practice and automatic evaluation, their electronic content is mostly focused on one scientific field). According to Průcha et al. (2009) and Ocelková (2012) is an i-textbook, an electronic version of a printed textbook in which interactive and multimedia elements such as videos, audio recordings, dictionaries, hypertext and web links, interactive maps, animations, simulations and interactive tasks that help to understand the curriculum better and individualize its content. They also increase motivation and 
integration between the student and the content of the textbook (Manzini et al., 1994). The same general principles and guidelines apply to the creation and use of i-textbooks as to textbooks in printed form (more Průcha, 1998). However, they also include other principles specific to electronic and i-textbooks (see Chapter 4). In this context, it is necessary to distinguish between electronic and itextbooks. According to Průcha et al. (2009), the electronic textbook is didactic texts that are not in print but the electronic form and possibly also in the online form. Not every e-textbook is so interactive. Balážovič (2016) understands interactivity as the ability of teaching aid to respond to stimuli from students, which electronic textbooks cannot do. The i-textbook must motivate the student to use it, activates it, provides him with quality feedback and enables him to manage the process of his learning process to the necessary extent. One of the possibilities of interactivity and feedback of the textbook can be an online selfassessment test. It can be integrated into a textbook as a web link. There are some freely available products on the market, such as Chamilo, PurposeGames, Socrative, LearningApps, Kahoot, etc. It is necessary to prefer those that allow feedback in text, not just point system. An interesting variant of i-books and map collections are the interactive talking exercise books with IRS pens (e.g. Šolcová et al., 2015).

The use of i-textbooks in the learning process is also justified by the research of psychologists while comparing the architecture of hypertext to the information structure of the human brain, in which individual concepts are connected in appropriate semantic contexts and associations into the net, but not linear (Mayer, 2010).

To create i-textbooks, it is possible to use one of the available editors for the ePub format, meeting the requirements for easy insertion of text, graphic objects, static and dynamic elements and has several useful functions for formatting and ensuring interactivity of the textbook. The best-known ePub editors include Blurb BookWright, Byeink (web platforms) and Book Creator (iOS and Android platforms), which, however, do not offer the use of more complex objects with implemented behavior (widgets). Other options include the free Sigil and eCub applications. Working in these editors is more challenging than just writing a document in a text editor, and for more complex formatting requires a user with knowledge of HTML5, JavaScipt, and cascade styles. More user-friendly commercial applications are Kitaboo (web platform) and PubCoder (macOS, Windows platforms), which offer to embed various widgets and their outputs are optimized for multiple devices and e-book formats. All requirements for creating multimedia and interactive textbook are also met by the free iBooks Author application (iOS platform). However, it has its distribution limitations due to the license terms of this application. 
Equipment for presenting i-textbooks is also essential for achieving the goals of the lesson or self-study. Trhan et al. (2015) consider mobile devices (tablets, readers) with a larger display, sufficient battery life (so that they can be used continuously throughout the study time) and with support for the most used formats for i-books (e.g. ePub format) to be the most suitable. However, i-books can also be read via desktop and laptop computers with an Internet connection (for example, the Windows operating system with a suitable program for reading the ePub format) or use an interactive whiteboard. An essential part of i-textbooks should be a website with information and methodological recommendations for teachers, or possibly an instructional video.

\section{Digital education technologies within teaching the subject of geography}

The content of geographical education is very suitable for the application of digital technologies (Demirci, Karaburun \& Kilar, 2013). Various aspects of the application of digital technologies in the teaching of geography have been addressed by Chandra and Lloyd (2008), Karolčík et al. (2016). Through digital technologies, it is possible to more effectively develop several of the skills and competencies required by the ISVP (ŠPÚ, 2015). In the document ICT across the curriculum - ICT geography (ICT across the curriculum, 2004), competencies such as information retrieval and evaluation, information processing, information sharing, and exchange of information were identified as critical competencies with the support of technology. The development of these competencies and related competencies is also possible in the example of a local country or local region, which is better grasped for students than distanced regions. Tomčíková (2010) pointed out the possibilities of applying digital technologies in creating maps and obtaining information about the local country from the Internet. Digital maps and map collections offer many possibilities (Google Earth, Google Maps, ZBGIS, Map Atlas of the Slovak Republic, OpenStreetMap, Mapire, Marble, StoryMap, Mapy.cz, MapMaker Interactiv and others). It is, e.g., resizing the map by zooming in on details that are not possible on classic maps, displaying historical images, using street view, virtual tours, various layers, map functions, etc. However, the potential for the use of educational technologies in geography is not only covered by maps. The necessary information can be searched in official databases (DATA cube, Enviroportal databases and ŠOP SR). Web and mobile applications with geographic games and quizzes (GeoGame, Seterra Geography, World Geography, Find a Hill, LandscapAR and others) also have educational potential. Digital educational technologies enable the use of interesting learning strategies and methods based on inductive approaches in the geography of the local country, such as research-oriented teaching, problembased teaching, case studies, project teaching, etc. 


\section{Methodology}

The paper aims to identify the most critical aspects of the implementation of i-textbooks and to propose recommendations for their creation based on the experience from the creation and evaluation of a specific i-textbook. Considering this goal, we have identified two research questions: 1. What are the essential aspects of creating i-textbooks? 2. Does the proposed i-textbook meet the set requirements?

The creation of the i-textbook "Horné Pohronie - the geography of the region" was preceded by the determination of the essential requirements. From the requirements for electronic teaching aids and educational software (Karolčík et al., 2015), we selected relevant requirements for i-textbooks, which we supplemented with other specific requirements, according to Ocelková (2012). Considering these requirements, we subjected the textbook to evaluation (online questionnaire) in four areas of relevant requirements (1. technical and technological requirements, 2. content, control, organization and processing of information, 3. didactic information processing, 4. psychological and pedagogical requirements). The evaluation of the i-textbook works with a strict (or ideal) model of quality evaluation, which compares the evaluated textbook with the ideal work. The individual requirements evaluated have different weights. Assessment is graded into three categories (Karolčík et al., 2015): 1. good elearning tool (in 3 out of 4 assessment areas it received on average more than 30 $\%$ ), 2. very good e-learning tool (in 3 out of 4 assessment more than $50 \%$ on average), 3. an excellent e-learning tool (on average more than $80 \%$ in 3 of the 4 assessment areas).

The evaluation aimed to determine the level of the i-textbook in general and within the monitored areas. An online structured questionnaire (Gavora et al., 2010) was used as an essential means of obtaining the data needed to carry out the survey. It helped us to collect the opinions of the 45 teachers of the subject of geography in primary schools and gymnasium and 25 students of specialization Teaching the subject of geography at the Faculty of Natural Sciences of Matej Bel University in Banská Bystrica. The detailed description of the research sample $(\mathrm{N}=70)$ is shown in Table 1:

\begin{tabular}{|l|c|c|c|}
\hline \multicolumn{1}{|c|}{ Respondents } & Female & $\begin{array}{c}\text { Mal } \\
\text { e }\end{array}$ & Total \\
\hline Primary school teachers & 15 & 10 & 25 \\
\hline Gymnasium teachers & 9 & 11 & 20 \\
\hline
\end{tabular}




\begin{tabular}{|l|c|c|c|}
\hline $\begin{array}{l}\text { Students of program } \\
\text { Teaching the subject of } \\
\text { geography }\end{array}$ & 12 & 13 & 25 \\
\hline Total & $\mathbf{3 6}$ & $\mathbf{3 4}$ & $\mathbf{7 0}$ \\
\hline
\end{tabular}

Tab. 1: Research sample $(N=70)$ of the questionnaire survey.

The questionnaire survey was conducted from October to December 2019. In addition to questionnaire items that surveyed sociometric data on respondents (age, gender, approbation, school), the research questionnaire contained 33 questionnaire items that reflected the set requirements for i-textbooks. The items are divided into the four areas mentioned above. We used elementary descriptive statistics to determine the percentage share within the evaluated areas. The questionnaire also included an open-ended question, intending to identify problem areas and lacks in the textbook. This information was the basis for its optimization. It is important to emphasize that the survey was conducted only on a small sample of teachers and students, so the conclusions can not be generalized and apply only to the evaluated i-textbook "Upper Pohronie Region - the geography of the region".

\section{Results}

The development and creation of i-textbooks require considering special conditions and meeting specific requirements in order to be successfully and effectively implemented in education. Based on the requirements for electronic teaching aids and educational software (Karolčík et al., 2015) and our experience, we formulated relevant requirements for i-textbooks:

- the i-textbook should be available for all standard platforms, devices and browsers

- using the i-textbook should be simple and intuitive,

- the content of the i-textbook should be processed at a high professional, formal and methodological level and should use the most modern information processing technologies, should respect the iŠVP,

- the content of the i-textbook should be open, offer various interactive elements and make the most of visualization and multimedia,

- the i-textbook should include educational activities supporting learning and cognition with the option of providing feedback,

- the i-textbook should take into account the pedagogical-psychological aspects of learning and cognition. 
Taking into account these input requirements, we created the i-textbook "Upper Pohronie Region - the geography of the region". It targets the students of gymnasiums and higher grades of elementary school students in the districts of Banská Bystrica and Brezno. Its use is directly for teaching or self-study in the home environment. From experience in creating and evaluating textbooks, we have identified several aspects, which we have described on the example of this textbook:

\section{Technical and technological properties of interactive textbook}

After clarifying the requirements for the final version of the textbook, an analysis of available software products focused on the creation of electronic interactive books in ePub3 and HTML format followed. Technically, we required the availability of the created textbook for all standard platforms, devices and web browsers, and its simple and easy download and opening. From many products, but only some of them met our requirements, we chose the Italian program PubCoder ver. 3 (www.pubcoder.com), designed to create e-books and textbooks with interactive and multimedia elements in ePub, xPub, HTML5 and KF8 formats. These formats are supported on common platforms (macOS, Linux, Windows, Android, iOS) of current mobile devices and computers. The program also met the requirement to export to HTML format (option to make the textbook available from the website). The created i-textbook is available at the website http://hpbook.fpv.umb.sk/ without the need for registration or other conditions and restrictions. Students can work with the textbook individually or in groups, provided they have a computer, tablet, reader or smartphone with an internet connection. The textbook can be downloaded and saved in the library of programs for reading electronic books (published ePub or xPub format) or used directly from a website via a web browser (HTML5 format).

It is not possible to determine whether the created textbook meets the required criteria without feedback from teachers and students. We obtained this valuable information from an online questionnaire. Within the 1st area - Technical and technological features, the respondents evaluated three sub-areas - installation and start-up process, stability and technologies used. The score of respondents $(\mathrm{N}$ $=70)$ in this area was 1,323 out of 1,540 points out of the maximum score $(85,9$ $\%$ ), while this area was evaluated better by teachers than students (Table 2).

\begin{tabular}{|c|c|c|c|c|}
\hline Subarea & Items & $\begin{array}{c}\text { Average } \\
\text { evaluation - } \\
\text { teachers } \\
(\%)\end{array}$ & $\begin{array}{c}\text { Average } \\
\text { evaluation - } \\
\text { students } \\
(\%)\end{array}$ & $\begin{array}{c}\text { Average } \\
\text { evaluation - } \\
\text { total (\%) }\end{array}$ \\
\hline
\end{tabular}




\begin{tabular}{|l|c|c|c|c|}
\hline $\begin{array}{l}\text { Installation and } \\
\text { start-up }\end{array}$ & 3 & 87,2 & 80,4 & 84,8 \\
\hline Stability & 2 & 87,2 & 86,0 & 86,6 \\
\hline Used technologies & 1 & 88,4 & 84,0 & 86,9 \\
\hline Total & $\mathbf{6}$ & $\mathbf{8 7 , 6}$ & $\mathbf{8 3 , 5}$ & $\mathbf{8 5 , 9}$ \\
\hline
\end{tabular}

Tab. 2:. Evaluation results of the 1st area-Technical and technological features of the i-textbook.

\section{Content, control, organization and information processing in the interactive textbook}

The deigned i-textbook is an additional source of information and tasks to currently printed textbooks of geography. Its content is related to the thematic unit Slovakia within the iŠVP Geography (ŠPÚ, 2015). Within this thematic unit, there is also space for the geography of the local country. Almost all relevant objectives of the IŠVP performance standard can be fulfilled or supported by the use of information about the territory, which students already partially know, are related to it and through an interactive electronic textbook also available information in various forms. We required that the content of the textbook be professionally correct, up-to-date and continuously up-to-date, appropriate to the age of the target group, that information in various graphic and cartographic formats, texts are divided and legible, essential terms are highlighted, etc. Also important is a clear, logical and well-thought-out organization of information and the overall structure of the textbook and a clear division of elements on the textbook side. Another critical requirement was, in particular, a clear and intuitive operation of the textbook. The content of individual chapters consists of a static and a dynamic part. The dynamic part consists of interactive elements controlled by touch gestures. They include photos and images with the option of zoom in. These control buttons allow you to open and close text fields, images, graphs, tables, animations, audio and video recordings; hypertext links to websites, databases and a register of terms, interactive maps, interactive and control HTML elements, self-assessment tests, browsing the content, etc. (Figure 1-2). Their task is the interactivity of the textbook, its adaptation to the interest and needs of the student; they increase the dynamics of working with the textbook. Much of the content of each page is initially hidden; only the introductory text and images are displayed. If interested, students have the option of displaying additional and expanding content (via touch buttons). In addition to interactivity, this also provides easier orientation in the textbook. Some of the textbook's features are related to the device and program for reading the ePub or xPub format textbook (e.g., full-text search, notes, bookmarks, etc.). 
Within the 2 nd area - Content, organization and information processing and control, the score of the respondents $(\mathrm{N}=70)$ were 2,588 out of 2,800 points as the maximum score $(92,4 \%)$, while this area was evaluated better by teachers than students (Table 3).

\begin{tabular}{|l|c|c|c|c|}
\hline \multicolumn{1}{|c|}{ Subarea } & Items & $\begin{array}{c}\text { Average } \\
\text { evaluation - } \\
\text { teachers } \\
(\mathbf{\%})\end{array}$ & $\begin{array}{c}\text { Average } \\
\text { evaluation - } \\
\text { students } \\
(\mathbf{\%})\end{array}$ & $\begin{array}{c}\text { Average } \\
\text { evaluation - } \\
\text { total (\%) }\end{array}$ \\
\hline Content & 8 & 91,9 & 91,6 & 91,7 \\
\hline $\begin{array}{l}\text { Organization and } \\
\text { information } \\
\text { processing }\end{array}$ & 2 & 94,7 & 89,6 & 93,1 \\
\hline Control & 3 & 96,3 & 93,3 & 95,2 \\
\hline Total & $\mathbf{1 3}$ & $\mathbf{9 4 , 3}$ & $\mathbf{9 1 , 5}$ & $\mathbf{9 2 , 4}$ \\
\hline
\end{tabular}

Tab. 3: Results of the evaluation of the 2 nd area - Content, control, organization and information processing of $i$-textbook.

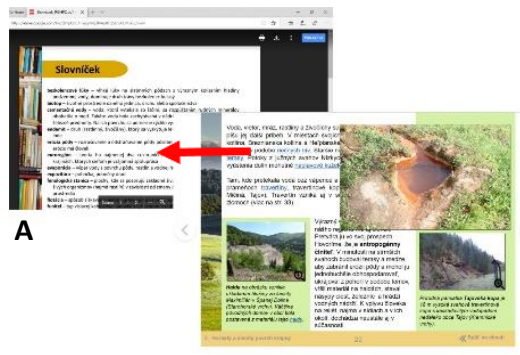

B

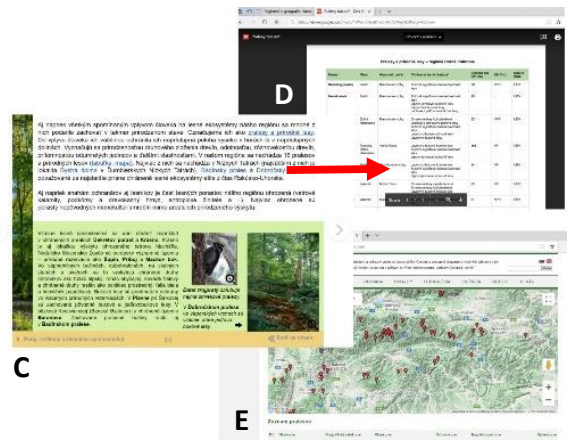

Fig. 1: Demonstration of interactive elements controlled by touch gestures. They are represented by photographs and images with the possibility of zoom in $(B)$ and hypertext links to websites $(E)$, databases $(D)$ and the register of terms (A) (source http://hpbook.fpv.umb.sk/). 

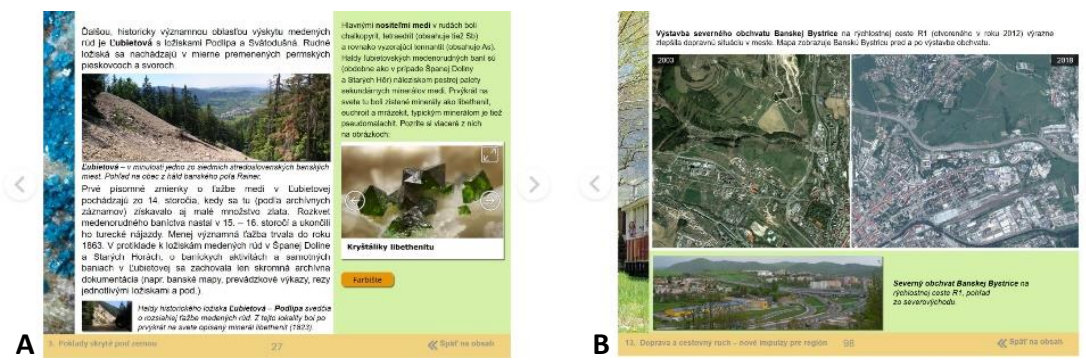

Fig. 2: Demonstration of interactive HTML elements - slide show (A) and visualization of historical and contemporary orthophotomap created in Juxtapose (B) (source http://hpbook.fpv.umb.sk/).

\section{Didactic processing in learning activities in the interactive textbook}

The electronic textbook must allow the teacher to use a wide range of teaching methods and procedures to motivate, activate, provide quality feedback to the student and enable him to manage the learning process as needed. Therefore, the textbook represents not only a source of information about the region but also a database of problem tasks from everyday life and ideas for school projects at the end of each chapter. The teacher can rely on it, for example, when checking students' homework using a textbook. Many tasks are interactive; their solution requires active work with the textbook and several links to hidden textbook content, various websites and applications such as Juxtapose, Google Maps, ZBGIS, OpenStreetMap, Mapire, PurposeGames, DATA cube and other databases that are integrated into the book as hyperlinks or HTML elements (Figure 3). Students can verify their knowledge and skills in finding information through self-assessment tests created in the Chamilo program (available on the online server of the website http://geo.fpv.umb.sk/chamilo/). Although this program was initially designed as an LMS system, it is also very suitable for creating online tests, which are run from the textbook as hypertext links. Chamilo offers a simple graphic design and a relatively simple user interface. The language barrier is also solved out, as the program has a Slovak translation. Part of these tests is the feedback that students receive automatically when done with solving - in addition to the correct results and points, comments are also displayed, which contribute to a better understanding of the problem and expand knowledge about the topic.

Within the 3rd area - Didactic processing of learning activities and motivation, we evaluated two sub-areas - didactic processing of information, motivation and activation of learning activities. The score of respondents $(\mathrm{N}=$ 
70 ) in this area was 1,785 out of 2,030 points of the maximum score $(87,9 \%)$, while this area was evaluated better by students than teachers (Table 4).

\begin{tabular}{|l|c|c|c|c|}
\hline \multicolumn{1}{|c|}{ Subarea } & Items & $\begin{array}{c}\text { Average } \\
\text { evaluation } \\
\text { teachers } \\
(\mathbf{\%})\end{array}$ & $\begin{array}{c}\text { Average } \\
\text { evaluation - } \\
\text { students } \\
(\mathbf{\%})\end{array}$ & $\begin{array}{c}\text { Average } \\
\text { evaluation - } \\
\text { total (\%) }\end{array}$ \\
\hline $\begin{array}{l}\text { Didactic processing } \\
\text { of information }\end{array}$ & 4 & 95,0 & 91,1 & 93,7 \\
\hline $\begin{array}{l}\text { Motivation and } \\
\text { activation of } \\
\text { learning activities }\end{array}$ & 3 & 79,9 & 87,0 & 82,2 \\
\hline Total & $\mathbf{7}$ & $\mathbf{8 7 , 4}$ & $\mathbf{8 9 , 1}$ & $\mathbf{8 7 , 9}$ \\
\hline
\end{tabular}

Tab. 4: Results of the evaluation of the 3rd area-Didactic processing of learning activities and motivation in the i-textbook.

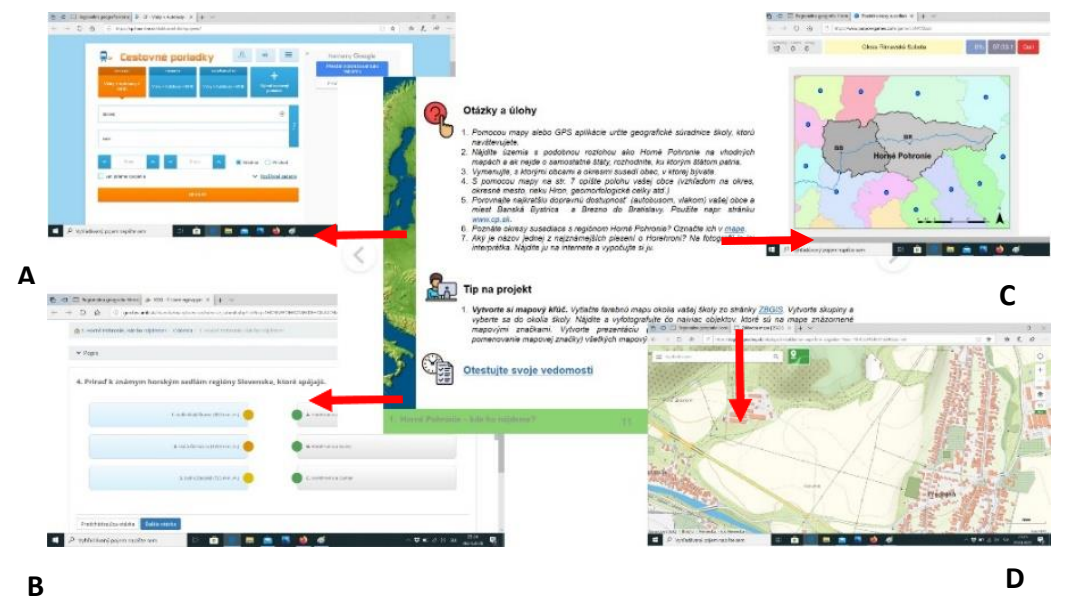

Fig. 3: Example of a part of the textbook with interactive tasks and hypertext links to used web applications such as Travel Itineraries (A), PurposeGames $(C)$, ZBGIS (D) and online test in Chamilo (B) (source http://hpbook.fpv.umb.sk/).

\section{Psychological and pedagogical aspects}

Other equally important requirements for an i-textbook are related to the psychological and pedagogical aspects of its use, e.g., considering the current 
level of cognitive development of students and encouraging their further cognitive development, considering the activity, constructivity, authenticity, social character, individual differences in learning activities, etc. For example, students have the opportunity to acquire not only knowledge but also their resources and skills while discovering. The content of the textbook and didactic tasks are created in elaborate contexts with reality and their practical use (Figure 4). Several tasks and project ideas require cooperation and communication of students when working in groups. The advantage of the textbook is the possibility to choose the pace of work, whether in a school or home environment, to pause it or to return to previous information. The textbook also takes into account individual differences that result from different types of students' preferred learning motivation. For example, for students with predominant performance motivation, self-assessment tests are appropriate at the end of each chapter (they provide feedback that allows students to evaluate and compare their performance), for students with predominant cognitive motivation, hyperlinks to the expanding textbook content are an advantage.

Within this area, the score of respondents $(\mathrm{N}=70)$ in this area was 2,319 out of 2,660 points from the maximum score $(87,2 \%)$, while this area was evaluated better by students than teachers (Table 5 ).

\begin{tabular}{|l|c|c|c|c|}
\hline \multicolumn{1}{|c|}{$\begin{array}{c}\text { Subarea- } \\
\text { considering: }\end{array}$} & Items & $\begin{array}{c}\text { Average } \\
\text { evaluation } \\
- \text { teachers } \\
(\mathbf{\%})\end{array}$ & $\begin{array}{c}\text { Average } \\
\text { evaluation } \\
- \text { students } \\
\text { (\%) }\end{array}$ & $\begin{array}{c}\text { Average } \\
\text { evaluation } \\
\text { - total (\%) }\end{array}$ \\
\hline $\begin{array}{l}\text { Current level of } \\
\text { cognitive development } \\
\text { of students and } \\
\text { motivation for students } \\
\text { in their cognitive } \\
\text { development }\end{array}$ & 1 & 73,8 & 84,0 & 77,1 \\
\hline $\begin{array}{l}\text { Activation in teaching } \\
\text { activities }\end{array}$ & 2 & 89,3 & 91,3 & 90,0 \\
\hline $\begin{array}{l}\text { Authenticity in } \\
\text { teaching activities }\end{array}$ & 2 & 86,3 & 90,7 & 87,6 \\
\hline $\begin{array}{l}\text { Social character in } \\
\text { teaching activities }\end{array}$ & 2 & 85,6 & 88,4 & 86,3 \\
\hline $\begin{array}{l}\text { Cognitive learning } \\
\text { theory }\end{array}$ & 2 & 98,3 & 95,0 & 97,1 \\
\hline Individual differences & 3 & 87,6 & 86,3 & 87,1 \\
\hline Total & $\mathbf{1 4}$ & $\mathbf{8 6 , 8}$ & $\mathbf{8 9 , 3}$ & $\mathbf{8 7 , 2}$ \\
\hline
\end{tabular}


Tab. 5: Results of the evaluation of the 4th area - Psychological and pedagogical aspects in the i-textbook.

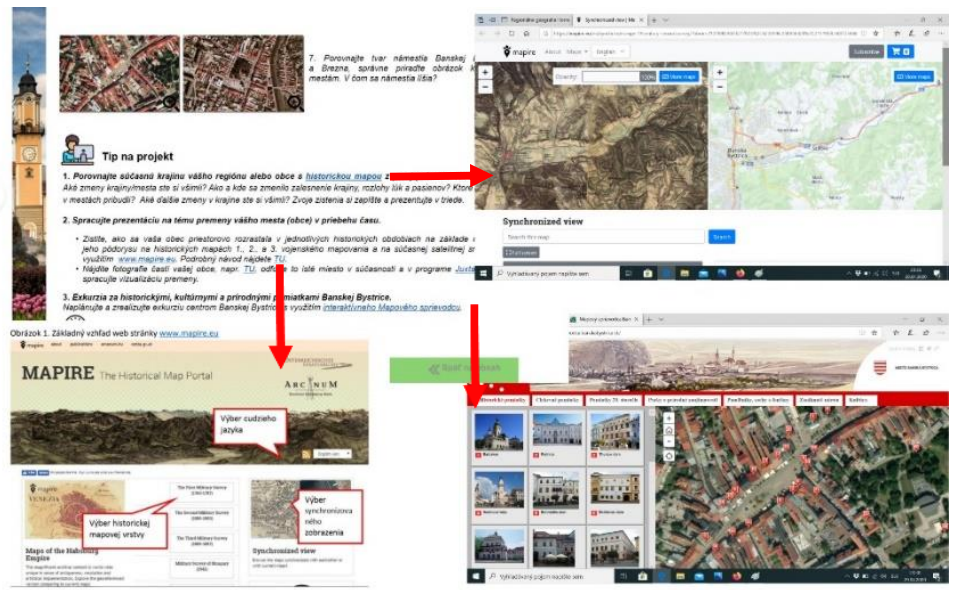

Fig. 4: Example of a part of the textbook with ideas for projects using hypertext links to web applications such as Mapire (B), Instructions for working with Mapire (C), Slovakia in historical photographs (D) and Mapsprievodca.banskabystrica $(E)$

\section{Conclusion}

(source http://hpbook.fpv.umb.sk/).

A necessary and essential prerequisite for the creation of quality and usable in school practice i-textbooks is the determination of specific requirements such as accessibility, ease of use, clarity, professionally and didactically well-processed content using the latest information processing technologies and a high proportion of interactive elements. It should also include various educational activities, considering the pedagogical-psychological aspects of learning and cognition, but also respect the relevant iŠVP. Based on these requirements, we created an itextbook "Upper Pohronie Region - the geography of the region" within the KEGA project. It is an electronic teaching aid that will allow teachers and students to develop knowledge about their region, but also has the potential to develop students in terms of attitudes and competencies. Students get to know the local country and the region in a broader context, which will support the development of their thinking and create the conditions for the integration of educational content into other subjects. As the i-textbook and its components represent and work with the most modern information and communication technologies, it supports the increase of digital competencies in students. In addition to the many 
mentioned advantages that i-textbooks offer, we should also highlight its limitations. Even today, for example, there are families and schools that do not have sufficient access to information and communication technologies, or they may fail and students may be limited in working with the i-textbook and look for alternative solutions. The results of the questionnaire survey, based on comparing various aspects of the created textbook with an ideal educational tool by the respondents, showed that the i-textbook "Upper Pohronie Region - the geography of the region" from teachers and students involved in the survey meets the requirements $(87,6 \%)$. As all the researched areas reached over $80 \%$ (from 85,9 $\%$ to $92,43 \%$ ) of the maximum evaluation, the textbook can be marked as an "excellent teaching aid" based on this evaluation. Based on the results of the survey, we also obtained an overview of the strengths and weaknesses of the evaluated i-textbook, which were used in its optimization. We are aware that whether this tool will succeed in school practice will be possible to assess only after its introduction into the teaching of geography. Therefore, our goal for the future will be to test its use in real school conditions, but also to create examples of models of didactic use of this teaching aid in school geography.

Acknowledgment: Educational Grant Agency of the Ministry of Education, Science, Research and Sport of the Slovak Republic KEGA under the Grant No. 015UMB-4/2018 and by the Slovak Research and Development Agency under the Grant No. APVV-18-0185.

\section{Literature}

Balážovič, L. (2016). Interaktívne učebné materiály vo vyučovaní geografie na ZŠ $\mathrm{s}$ využitím technológie Chamilo. Inovácie a trendy $v$ prírodovednom vzdelávaní. Bratislava: Univerzita Komenského v Bratislave, Prírodovedecká fakulta. s. 7-11. ISBN 978-80-223-4175-2.

Csachová, S. (2020). Using WebGIS Platforms and Inquiry-based Activities to Teach about World Political Map and World Population. Online Review of International Geographical Education. DOI: 10.33403/rigeo.678026.

Chandra, W., \& Lloyd, M. M. (2008). The methodological nettle: ICT and student achievement. British Journal of Educational Technology, 39(6). 10871098. DOI: 10.1111/j.1467-8535.2007.00790.x.

Chen, Z., Stelzer, T., \& Gladding, G. (2010). Using multimedia modules to better prepare students for introductory physics lecture. Physical Review Special Topics - Physics Education Research, 6(1). 1554-9178. DOI: 10.1103/PhysRevSTPER.6.010108.

Donnell, J., Singhose, W., \& Kivila, A. (2014). An interactive textbook for introductory engineering design. Paper presented at the CSEDU 2014 - 
Proceedings of the 6th International Conference on Computer Supported Education, 1. 174-181. DOI: 10.5220/0004763601740181.

Demirci, A., Karaburun, A., \& Kilar, H. (2013). Using Google Earth as an educational tool in secondary school geography lessons. International Research in Geographical and Environmental Education, 22(4). 277-290. DOI: 10.1080/10382046.2013.846700.

Gavora, P., Koldeová, L., Dvorská, D., Pekárová, J., \& Moravčík, M. (2010). Elektronická učebnica pedagogického výskumu. [cit. 2020-04-30]. Dostupné z: http://www.e-metodologia.fedu.uniba.sk.

Grant, M. M., \& Mims, C. (2009). Web2.0 inteacher education: Characteristics, implications and limitations. Wired for learning: An educators guide to Web 2.0, Memphis: University of Memphis, 343-360. ISBN 978-1-60752-096-2.

Gregorová, B. (2018). Interaktívne digitálne učebnice z geografie pre základné školy. Geografická revue, 14(2). 42-63. DOI: 10.24040/GR.2018.14.2.42-63.

Karolčík, Š́., Čipková, E., \& Mázorová, H. (2016). Application of digital technologies in the geography teaching process from the teachers' perspective. International Research in Geographical and Environmental Education, 25(4). 328-343. DOI: 10.1080/10382046.2016.1207992.

Karolčík, Š., Zilinskiene, I., Slotkiene, A., \& Čipková, E. (2019). Analysis of eLearning Environment for Geography: Opportunities for Personalized Active Learning. Baltic Journal of Modern Computing, 7. 405-418. DOI: 10.22364/bjmc.2019.7.3.07.

Kormancová, Ž. (2018). Edukačný softvér. [cit. 2020-04-30]. Dostupné z: https://prezi.com/p/bkudcvnez1wt/edukacny-softver

Manzini, G. M., Ticca, A., \& Zanetti, G. (1994). Interactive Books. International Journal of Modern Physics, 5(05). 785-789. DOI: 10.1142/S0129183194000891. Mayer, R. E. (2010). Techniques that reduce extraneous cognitive load and manage intrinsic cognitive load during multimedia learning. Cognitive load theory, 131-152. DOI: 10.1017/CBO9780511844744.009.

Mayer, R. E., Heiser, J., \& Lonn, S. (2001). Cognitive Constraints on Multimedia Learning: When Presenting More Material Results in Less Understanding. Journal of Educational Psychology, 93(1). 187-198. DOI: 10.1037//00220663.93.1.187.

Mázorová, H. et al. (2010). Využitie informačných a komunikačných technológií v predmete Geografia pre stredné školy. Učebný materiál - modul 3. [cit. 202004-28]. Dostupné z: http://files.virtual-lab.sk/MVP/eGeografia_SS.pdf

Ocelková, P. (2012). Interaktivní učebnice ve vyuce vzdělávací oblasti člověk a príroda. [cit. 2020-04-28]. Dostupné z: https://zemepisnove.osu.cz/wpcontent/uploads/1.5.Interaktivni_ucebnice.pdf 
Polly, D., Mims, C., Shepherd, C. E., \& Inan, F. (2010). Evidence of impact: Transforming teacher education with preparing tomorrow's teachers to teach with technology (PT3) grants. Teaching and Teacher Education, 26(4). 863-870. DOI: 10.1016/j.tate.2009.10.024.

Průcha, J. (1998). Učebnice: teorie a analýzy edukačního média: př́ručka pro studenty, učitele, autory učebnic a výzkumné pracovniky. Brno: Paido. 148 s. ISBN 80-85931-49-4.

Průcha, J., Walterová, E., \& Mareš, J. (2009). Pedagogický slovník. Nové, rozš. a aktualiz. vyd. Praha: Portál. 395 s. s. ISBN 978-80-7367-647-6.

Martin, S., Diaz, G., Sancristobal, E., Gil, R., Castro, M., \& Peire, J. (2011). New technology trends in education: Seven years of forecasts and convergence. Computers \& Education, 57(3), 1893-1906. DOI: 10.1016/j.compedu.2011.04.003.

Stelzer, T., Gladding, G., Mestre, J. P., \& Brookes, D. T. (2009). Comparing the efficacy of multimedia modules with traditional textbooks for learning introductory physics content. American Journal of Physics, 77(2), 184-190. DOI:10.1119/1.3028204.

Šolcová, L., Baková, J., \& Trnka, M. (2015). Geografia. Interaktívna cvičebnica pre stredné školy. Bratislava: Mardur s.r.o., 176 s. ISBN 978-80-89641-82-6.

ŠPÚ (2015). Inovovaný štátny vzdelávací program pre gymnáziá - Geografia. [cit. 2020-04-28].

Dostupné $\mathrm{z}:$ http://www.statpedu.sk/files/articles/dokumenty/inovovany-statny-vzdelavaciprogram/geografia_g_4_5_r.pdf

Tomčíková, I. (2013). Kognitívne ciele vo vyučovaní geografie miestnej krajiny na základnej škole. Geographia Cassoviensis, 7. Košice: Univerzita Pavla Jozefa Šafárika v Košiciach, s. 157-162. ISSN 2454-0005.

Trhan, P., Gáperová, S., \& Gáper, J. (2015). Elektronická učebnica pre iPad. DIDINFO 2015. Banská Bystrica: Univerzita Mateja Bela, Fakulta prírodných vied v Banskej Bystrici. s. 164-168. ISBN 978-80-557-0852-2.

Wellington, J. (2005). Has ICT come of age? Recurring debates on the role of ICT in education, 1982 - 2004 May. Research in Science and Technological Education, 23(1). 25-39. DOI: 10.1080/02635140500068419. 